\title{
Mycosphere Essay 18: Biotechnological advances of beneficial fungi for plants
}

\author{
Kumar $\mathbf{P}^{1,4}$, Pagano $\mathbf{M}^{2^{*}}$, and O'donovan $\mathrm{A}^{3}$ \\ ${ }^{1}$ School of Biotechnology, Yeungnam University, Gyeongsan, Gyeongbook 712-749, Republic of Korea \\ ${ }^{2}$ Biological Sciences Institute, Federal University of Minas Gerais, Brazil \\ ${ }^{3}$ School of Natural Sciences, Discipline of Biochemistry, National University of Ireland Galway, Ireland \\ ${ }^{4}$ Current Address: Department of Forestry, North Eastern Regional Institute of Science and Technology (Deemed \\ University), Nirjuli-791109, Arunachal Pradesh, India
}

Kumar P, Pagano M, O’Donovan A. 2017 - Mycosphere Essay 18: Biotechnological Advances of Beneficial Fungi For Plants. Mycosphere 8(3) 445-455, Doi 10.5943/mycosphere/8/3/6

\section{Introduction}

There is a greater need to consider microbial interactions in the plant-soil system as plants are essential for sustaining human health. Most plant species associate with microorganisms in a benefic way, for example, legumes associate with rhizobial bacteria, and most plants associate with mycorrhizas and/or endophytic microorganisms (Bonfante \& Genre 2010, Smith \& Read 2008). Saprobe fungi microorganisms can break down cellulosic remains to simple sugars, providing nutrients for other microorganisms, such as arbuscular mycorrhizal fungi (AMF) (Radford et al. 1996). Saprophytic fungi Trichoderma harzianum, help in root colonization by arbuscular mycorrhizal fungi and plant growth (Arriagada et al. 2009 a,b).

It is known that the soil biota, especially in a fertile soil, can create and modify their habitat, influence soil health, and also help regulate greenhouse gases (Fortuna 2012). Among soil biota, immeasurable microorganisms (bacteria, fungi, archaea, algae and cyanobacteria) live on the soil or pedosphere but only a portion of them have been identified (Fortuna 2012). In 2013, Yang et al. compiled information on phytosphere microorganisms and their benefits. The interaction of ecosystem with phytobiome of plant tissues which includes many beneficial, mutualistic, symbiotic microorganisms and earlier identified as obligate endophytes is needed an underpinning research demand (Xia et al., 2014).

Rhizosphere, the zone of soil under the influence of plant roots (Sylvia et al. 2005), has soil (soil $\mathrm{pH}$, structure, oxygen availability) along with the altered antimicrobial concentration provides a source of dead root and rich-carbon exudates, important for plant nutrition (Marschner et al.1986, Dennis et al. 2010). Thus, the rhizospheric microorganisms can benefit plant health; which is of increasing agronomic interest. The rhizospheric microbiome can provide phytohormones and other nutrient which improve the growth, overcomes with phytopathogens and assist plants against others abiotic stresses (drought, heat and salt) (Mendes et al. 2011, Firakova et al. 2007). These microorganisms are selected in niches and interact with hosts to reside in the endophytic compartments, which is found inside the roots being symbionts or pathogens (Schulz et al. 2006). Among microorganisms associated with plants, most relevant symbionts are rhizobia and mycorrhizal fungi; however, other partners are especially studied in order to improve plant health. This review identifies major outlines with respect to the complex 
interactions occurring between the different microorganisms and plants, which may well influence plant health.

\section{Benefits from Arbuscular mycorrhizal fungi}

Arbuscular mycorrhizal fungi (AMF) are important members of the soil microbial community and play a very crucial role in plant growth promotion, plant protection and soil quality improvements. These AMF are widely spread in agricultural systems and are beneficial for organic farming because they act as a natural biofertiliser and improve plant growth and yield. These are play a crucial roles in plant growth and health by improving nutrient uptake (especially inorganic Phosphate), macronutrients ( $\mathrm{P}, \mathrm{N}, \mathrm{K}$ and $\mathrm{Mg}$ ) and micronutrients and improving water uptake by their host plant (Ryan \& Graham 2002). They improve drought resistance (Augé et al. 1994), tolerance to salinity and heavy metals and also protection against soil born pathogenic fungi and nematodes (Smith \& Read 2008). They also help increase resistance to foliar-feeding insects (Gange \& West 1994).

The use of fertilizers and biopesticides, monoculturing and other agricultural practices can adversely affect AMF; however, organic agriculture prohibits some of the most detrimental practices and thus AMF populations may be increased. Mycorrhizal associations are commonly found in both wild and cultivated plants; however, Brassicaceae and Cyperaceae usually do not associate with AMF. However, mycorrhizal colonization and beneficial effects to the plant species are not well understood. Moreover, highly mycorrhizal associated plant species may positively impact coexisting plants with respect to mycorrhizal colonization and nutrient acquisition, but the effects on poorly mycorrhizal dependent plant species are less known. Yang et al (2015) experimentally proved that, the symbiotic association with the leguminous tree (Robinia pseudoacacia) and the appropriate AMF species (Funneliformis mosseae and Rhizophagus intraradices) could be a useful approach for the phytostabilization and ecological restoration of lead $(\mathrm{Pb})$ polluted soils The best explored example of mutualistic symbiosis with the plant is the mycorrhizal fungi and nitrogen fixing rhizhospheric bacterial. These mutual relationships are beneficial and helpful to plat in increasing plant growth, yield and tolerance to biotic and abiotic stresses. These organisms can grow, propagate and interacts with individual cells as well as multitropic communities. Various researchers revealed that bacteria play an important role in association with fungal spores (Walley \& Germida 1997) and hyphae (Lumini et al. 2007) during the interactions between plants and mycorrhizal fungi. These beneficial properties in sustainable agriculture and soil health, increasing interest in topic worldwide.

Plants associate with microorganisms, such as symbionts rhizobia and mycorrhizal fungi; however, other partners are especially important such as Trichoderma spp. (Fig. 1). Almonacid et al. (2015) tested the effect of dual inoculation with AMF and saprophytic fungi (T. harzianum) on a combination of wheat straw and sewage sludge remains and determined their effect on the dry weight of tomato and on chemical and biochemical properties of soil. They reported this practice is an interesting option as a biofertilizer to improve plant growth and biochemical properties of soils.

It is known that saprobe fungi can disrupt cellulosic materials providing energy fonts for other microorganisms such as Coriolopsis rigida and T. harzianum that can present increased root colonization by AMF and plant growth (Arriagada et al. 2009a,b).

In this sense, plant associations with Trichoderma and dark septate fungi are increasingly studied. However, mycorrhizal interactions may have important functions in terrestrial ecosystems, being a topic of accelerated developing research. The arbuscular mycorrhizal fungi (AMF) are being specially mined due to their multiples functions in terrestrial ecosystems. These plant-soil symbionts can perform better under stressful conditions and the increasing recognition of their importance led to an increasing number of groups (mostly in Ecology sciences) worldwide. AMF structures such as total root colonized and percent root length colonized by arbuscules can be used to estimate AMF abundance within a plant or ecosystem. The extraradical 
hyphae of AMF extend from roots into the surrounding soil much further than plant roots and establish the mycorrhizosphere (Azcón 2014).

The study of AMF in different agroecosystems can contribute to better understanding of the effect of global change on plants and soil associated communities. Many crops associate with AMF and this symbiosis should be monitored with respect to the effects of global change. It is known that land-use intensity will increase in the future for both food and bioenergy production; however, long rotations are not deemed practical (reviewed by Bennet et al. 2012).

Notably, there is an increased interest in phytobiomes, which includes mutualistic endophytes, pathogens and symbionts that interact with plants. A numbers of microbes as noted within plant tissue than those previously identified as obligate endophytes (Xia et al., 2014). For example, many bacterial phyla and four fungal phyla were found associated with commercial crops such as tomato phytobiome (Xia et al. 2014).

Increasingly studies of phytobiomes (Table 1) have shown that microbial interactions between AMF, Trichoderma harzianum, Aspergillus niger and plant roots are widespread in natural environments providing various benefits to the host plant. In this sense, Singh (2015) showed that AMF combined with $T$. harzianum and A. niger interactions are important in determining the outcomes of plant competition and biocontrol of Fusarium wilt disease. Moreover, Xia et al. (2015) also showed higher endophyte abundance and diversity in organically cultivated tomato, corn, melon, and pepper, compared to conventional cultivation.

These findings point to the importance of sustainable cultivation systems to achieve the greatest benefit for the phytobiome. Further studies on the phytomicrobiome will help improve efficiencies in crop cycles (Smith et al. 2005).

\section{Benefits of Trichoderma spp. in crop protection and improvements}

Plant growth and improvement is predominantly performed by the promising rhizoshpheric fungus Trichoderma spp. and bacteria Azotobacter. Trichoderma being a virulent plant symbiotic fungus provides resistance to pathogenic microbes and plays promising role as a biocontrol agent for crop improvement. Through mycoparasitism mechanism, it induces resistance in plants against pathogens by producing antibiotics and competes for nutrition (Brotman et al. 2010).

Trichoderma harzianum T-22 was able to decrease the amount of the toxin fusaric acid, secreted by Fusarium oxysporum f. sp. gladioli, harmful to Gladiolus grandiflorus corms (Nosir et al. 2011). Trichoderma species and Piriformospora indica not only suppresses leaf pathogens but also protects plants from rhizospheric pathogens.

Trichoderma spp. are found naturally in soils of nearly all types and in other habitats. However, for agricultural purposes (e.g. for biocontrol of pathogens or to promote plant growth) they may be added as a seed treatment or directly to the soil. If applied as a seed treatment the best strains readily colonize the roots of the crop and will persist for up to 18 months after application (Harman 2000b). Different strains of Trichoderma are used as biocontrol agents to control a number of pathogenic fungi, although some strains are more effective than others. Several reputable companies manufacture products that, for example in the USA, are legally registered for control of specific pathogens (Harman 2000b). Trichoderma may also be applied to improve the rate of plant growth, in particular to increase development of a deep root system which can help plants such as maize, turfgrass and ornamentals to tolerate drought (Harman 2000b).

Biocontrol agents are known to deliver an extensive variety of consequences for plants. Trichoderma spp. used as biocontrol agents are known to control infection by pathogens through, for example, mycoparasitism or by the creation of antimicrobial compounds. Trichoderma is also known to advance or repress plant development (Contreras-Cornejo et al. 2009). Diverse types of Trichoderma exist in the rhizosphere and infiltrate plant roots, colonizing the epidermis and a few cells below (Harman et al. 2004). This opportunistic, facultative beneficial interaction between fungus and plant is determined by the capacity of Trichoderma to detect sucrose or different nutrients from the plants, in exchange for boosting plant resistance against attacking pathogens and enhancing photosynthetic capacity (Vargas et al. 2011). The proximity of Trichoderma spp. in 
the rhizosphere summons a composed transcriptomic, proteomic and metabolomic reaction in the plant (Shoresh \& Harman 2008). This response by the plant is frequently gainful, enhancing root growth and development, crop yield and resistance to pathogens.

Colonization infers the capacity to follow and perceive plant roots, enter the plant and withstand lethal metabolites delivered by the plants in response to attack by a remote organic entity. Trichoderma strains must colonize plant roots before the plant responds by producing antimicrobial compounds as a defence mechanism against microbial attack (Harman et al. 2004). Trichoderma spp. can build enduring colonizations on the surface of plant roots and enter into the epidermis where plants secrete antimicrobial compounds such as phytoalexins, phenolic compounds, terpenoids, flavonoids and glycones as part of systemic plant reactions against fungal pathogens.

Interactions between T. virens and arabidopsis studied by Contreras-Cornejo et al. (2009) and reported that fungal association increase the biomass production and promotes the lateral root growth through an auxine-dependent mechanism. Using a gene knockout technique, Viterbo et al. (2010) reported on the part played by ACC (1-aminocyclopropane-1-carboxylate) deaminase in regulation of canola (Brassica napus) root growth promotion by Trichoderma asperellum. In any case, Trichoderma secretes small cysteine-rich hydrophobin-like proteins to encourage connection. Entrance into the root is encouraged by secretary expansin-like proteins with cellulose-binding modules and endo-polygalacturonase (Brotman et al. 2010, Moran-Diez et al. 2009). Once infiltration occurs in the root, the fungus begins to grow and develop intercellularly, albeit being restricted to the epidermal layer and a few cells of the cortex immediately below the epidermis. T. koningii has been found to suppress phytoalexin production during colonization of Lotus japonicus roots (Masunaka et al. 2011).

\section{Trichoderma as biofertilizer and in plant development}

The addition of biofertilizers to soil can improve the retention of nutrients in plants and may encourage soil richness and increased harvest yields. Root colonization by Trichoderma strains has a beneficial effect on plants by improving resistance to abiotic stress and uptake of nutrients, as well as increasing root development. Crop productivity in fields can increase up to $300 \%$ after the addition of Trichoderma hamatum or T. koningii as biofertilizer. However, there are very few reports on strains that produce growth factors that have been detected and identified in the laboratory (auxins, citokinins and ethylene) (Arora et al. 1992). An increase in seed germination was observed when seeds were isolated from Trichoderma strains by a cellophane film, which demonstrates that Trichoderma strains secrete plant-development-advancing elements (Benitez et al. 1998).

According to Chang et al. (1986) improved germination, a fast rate of blooming and increased height and weight of specific plants, namely pepper and chrysanthemums, were observed when soil was treated with conidial suspensions of T. harzianum. Shivanna et al. (1994, 1996) recorded increased development of wheat and soybean under nursery conditions when treated with Penicillium and Trichoderma. They further expressed that the reaction varied when the same was attempted in field conditions yet increases in yield were perceived at times. $T$. harzianum strain T-203 enters the roots and acts like a mycorrhizal growth, advancing development (Kleifield \& Chet 1992). Trichoderma spp. are known to control minor pathogens such as Pythium sp. (Ahmad \& Baker 1988, Harman et al. 1989) and in this roundabout way advance development.

\section{Trichoderma induces plant resistance to pathogens}

The capacity of Trichoderma strains to protect plants against attack by root pathogens has long been attributed to a hostile impact against the intrusive pathogen (Chet et al. 1997). Colonization of the rhizosphere by Trichoderma strains protect plants against various classes of pathogens (viral, bacterial and fungal pathogens), which indicates the incitement of responses that are similar to 
plant resistance mechanisms, like Induced systemic resistance (ISR), systemic acquires resistance (SAR) and hypersensitive response (HR) (Harman et al., 2004).

Activation of plant resistance mechanisms do not necessarily need the presence of the live form of the pathogen as plant genes react to elicitors. Trichoderma elicitors might be metabolites that may bring about a combination of phytoalexins, pathogenesis-related (PR) proteins and other compounds produced by the plant, which increases protection against a few plant pathogens including microorganisms (Elad et al. 2000, Dana et al. 2001) and resistance to adverse abiotic conditions. Yedida et al. (2000) showed that inoculation of cucumber roots with T. harzianum (strain T-203) resulted in the production of PR proteins, including various hydrolytic chemicals. Plants react promptly to Trichoderma intrusion by rapid particle fluxes and an oxidative burst, subsequently demonstrated by the presence of a combination of callose and polyphenols (Shoresh et al. 2010). These events include salicylic acid (SA) and jasmonic acid/ethylene (JA/ET) signalling, resulting in the whole plant gaining varying degrees of resistance to pathogen assault. This reaction is most ordinarily known as JA/ET- mediated ISR and takes after the reaction activated by PGPR. According to recent discoveries (Yoshioka et al. 2012), larger inoculums of Trichoderma may enact an SA-mediated SAR reaction, looking like to that summoned by necrotrophic pathogens. The signalling events prompt ISR. An atomic cross-talk between plant (cucumber) and $T$. virens might evidently trigger a downstream guard reaction by ramifications of MAPK (mitogen-activated protein kinase) (Viterbo et al. 2005).

Some newly discovered Trichoderma spp. (phylogenetic investigation revealed a recent evolution), namely Trichoderma stromaticum, Trichoderma amazonicum and Trichoderma evansii, appear to have an endophytic relationship with plants, but they are not involved with the soil/rhizosphere (Mukherjee et al. 2012). The Endophyte Trichoderma species promot the transcriptional level changes in plants and also protect from various biotic and abiotic stresses (Bailey et al. 2006; Bae et al. 2009). Few of these endophytes produced appressoria-like structure when they colonize the surface of grandular trichomes (Bailey et al. 2006). This is one example where Trichoderma utilizes a 'non-root' mode of passage into the plant.

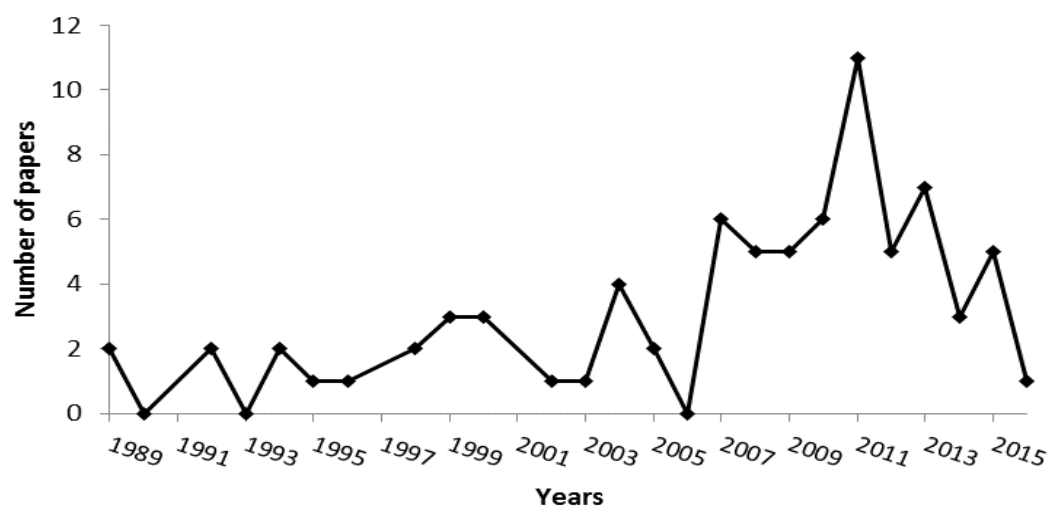

Fig. 1 - Number of papers on arbuscular mycorrhizas and Trichoderma published annually since 1989, included in SCOPUS. Only those papers that had appeared in SCOPUS by January 2017 are included.

Table 1 Journal articles dealing with beneficial fungi for plants.

\begin{tabular}{ll}
\hline Key words & Number of journal articles \\
\hline Beneficial fungi + Mycorrhiza & 581 \\
\hline Trichoderma + Mycorrhiza & 124 \\
\hline Phytobiome & 14 \\
\hline
\end{tabular}

Database survey conducted on January 2017 (SCOPUS); AMF = arbuscular mycorrhizal fungi. 


\section{Gliocladium as biocontrol agent and Plant growth promotor}

Gliocladium, an asexual common fungus of soil, is a parasite to many plant pathogens (Viterbo et al. 2007). Gliocladium penicilloides and Gliocladium virens were transferred to genus Trichoderma. Gliocladium catenulatum, parasitic to Sporidesmium and Fusarium spp., can annihilate the host fungus by direct hyphal contact via pseudoappressoria (Punja \& Utkhede 2004, Viterbo et al. 2007). Gliocladium catenulatum-JI446 has been used commercially to reduce the impact of damping off disease caused by Pythium ultimum and Rhizoctonia solani (Paulitz Belanger 2001, Punja \& Utkhede 2004). G. virens is also used as a biocontrol agent against a wide range of pathogens like Pythium ultimum and Rhizoctonia solani (Hebbar \& Lumsden 1999, Viterbo et al. 2007). The fungus produces metabolites such as gliotoxine with anti-bacterial, fungal, viral and anti-tumor properties. Molecular studies proved that the Trichoderma and the G. virens are closely related, so it was suggested that this taxon should be denoted as $T$. virens (Hebbar \& Lumsden 1999, Paulitz \& Belanger 2001, Punja \& Utkhede 2004). G. virens significantly controlled the growth of Alternaria alternata, Chaetomium spp., Penicillium citrinum, Aspergillus niger, A. flavus, Rhizopus nigricans and Fusarium oxysporum fungal species isolated from the stored seed (Agarwal et al. 2011).

\section{Piriformospora indica as plant growth promotor}

Verma et al (1998) discovered the Piriformospora indica (Genus-Piriformospora, OrderSebacinales), an endophytes with root colonizing efficiency associated orchid plants from India. This is a monotypic fungus of Piriformospora genus. P. indica, a plant growth promotor fungi form typical pyriform chlamydospores. Moreover, this axenically cultivable phytopromotional, biotrophic mutualistic root endosymbiont has similar abilities to that of AMF. The fungi colonize the roots of a wide range of higher plants improving nutrient uptake, disease resistance, stress tolerance and growth-promotion (Unnikumar et al. 2013). Growth promotion activity was observed in different plants such as Zea mays, Nicotiana tabaccum, Glycine max, Pisum satium, Withania somnifera and Spilanthes calva (Rai et al. 2001, Verma et al. 1998), also in timber-yielding and medicinal plants.

Association of beneficial fungi with plant roots is widespread among terrestrial plants species and play a crucial role in improving host plant health. The Sebacinales order fungi are distributed worldwide with high diversity at morphological and physiological levels (Weiss et al., 2011). P. indica is one of the most studied fungi for its plant growth promotion activity and stress resistance (Varma et al., 1999, Franken 2012). P. indica capable to colonize with the root of gymnosperm and angiosperm both and the colonization id restricted to the rhizodermis (Deshmukh et al., 2006). Ethylene is necessary for the colonization and induction of host responses (Camehl et al., 2010). During the colonization phases, the gene responsible for the biosynthesis of gibberellic acid and abscisic acidcan be induced (Schäfer et al. 2009). The fungi can be culture in bioreactors for mass production biofertilizer (Qiang et al. 2011).

More than 150 plant species interact with $P$. indica. Among them, horticultural, agricultural, medicinal and other important plants were reported, Oryza sativa, Zea mays, Tridax procumbans, Nicotiana tabacum, Arabidopsis thaliana and Brassica oleracea var capitata have been shown to improved seed germination and seed formation (Varma et al. 2012). Better plant growth was reported in several crops viz. Oryza sativa, Phaseolus vulgaris, Solanum nigrum, Brassica oleracea var capitata, Brassica nigra, Nicotiana tabbacum, Saccharum officinarum, Tridax procumbans and Zea mays (Varma et al. 2012). P. indica also interacts with medicinal plants such as Artemisia annua, Abrus precatorius, Azatarichta indica, Bacopa monniera, Curcuma longa, Linum album, Stevia rebaudiana, Trigonella foenum-graecum, to name just a few (Goltapeh \& Danesh 2006, Oelmüller et al. 2009, Das et al. 2012).

$P$. indica is very effective when it was inoculated with various crops. Commercialization of $P$. indica will be possible after the defining the parameter for inoculation at the specific time, quantity and type of soil. The endophyte can reduce the uses of chemical fertilizers; improve crop 
yield, plant resistance and biotic and abiotic tolerance (Unnikumar et al., 2013). P. indica also help in improving plant growth and productivity along with seed germination (Ansari et al., 2014).

\section{Conclusion}

Beneficial fungi contribute to plant growth and productivity. The above reviewed articles consistently report the association of plants with soil fungi and the benefits to the plant are reported extensively. Arbuscular mycorrhizal fungi and biocontrol agents such as Trichoderma and Gliocladium spp. summarise just a few of the beneficial fungal characteristics that improve plant cultivation. This review condenses the beneficial fungal characteristics that are utilised to promote biotechnological advantages for plants. Creating a sustainable economy and protecting our environment are, more than ever before, dominant topics in our everyday life. Increasing demands on our agricultural industry due to increasing population and energy crop production demands more efficient crop management. Positively, the focus is shifting to sustainable organic farming. This shift will require more from biocontrol agents and plant growth promotors in plant protection and as biofertilizers. Continuous research in this topic will aid innovation and advancements in biotechnologically beneficial fungi in relation to plant production.

\section{Acknowledgements}

Author PK and MCP write and did the editing of manuscript. Author OA help in finalize manuscript. Authors thankful to Dr. Vijai K. Gupta for help and support in writing this article.

\section{References}

Agarwal T, Malhotra A, Trivedi PC, Biyani M. 2011 - Biocontrol potential of Gliocladium virens against fungal pathogens isolated from chickpea, lentil and black gram seeds. J Agricultural Technology 7(6), 1833-1839.

Ahmad JS, Baker R. 1988 - Implications of rhizosphere competence of Trichoderma harizanum. Canadian Journal of Microbiology 34, 229-234.

Almonacid L, Fuentes A, Ortiz J, Salas C., Garcia-Romera I, Ocampo J, Arriagada C. 2015 Effect of mixing soil saprophytic fungi with organic residues on the response of Solanum lycopersicum to arbuscular mycorrhizal fungi. Soil Use and Management 31, 155-164.

Ansari MW, Gill SS, Tuteja N. 2014 - Piriformospora indica a powerful tool for crop improvement. Proceedings of Indian Academy of Science 80, 317-324.

Arora DK, Elander RP and Mukerji KG (eds) 1999 - Handbook of Applied Mycology. Fungal Biotechnology, Vol. 4. Marcel Dekker, New York.

Arriagada C, Sampedro I, Garcia-Romera I and Ocampo JA. 2009a - Improvement of growth of Eucalyptus globulus and soil biological parameters by amendment with sewage sludge and inoculation with arbuscular mycorrhizal and saprobe fungi. Science of the Total Environmental 407, 4799-4806.

Arriagada C, Aranda E, Sampedro I, Garcia-Romera I, Ocampo JA. 2009b - Contribution of the saprobic fungi Trametes versicolor and Trichoderma harzianum and the arbuscular mycorrhizal fungi Glomus deserticola and G. claroideum to arsenic tolerance of Eucalyptus globulus. Bioresource Technology 100, 6250-6257.

Augé RM, Duan X, Ebel RC, Stodola AJW. 1994 - Nonhydraulic signalling of soil drying in mycorrhizal maize. Planta 193, 74-82.

Azcón R. 2014 - Mycorrhizosphere: The role of PGPR. In: Morte, A, Varma, A. (eds.) 107-144. Root engineering. Springer, Berlin.

Bae H, Sicher RC, Kim MS, Kim SH, Strem MD, MeInice RL, Bailey BA. 2009 - The beneficial endophyte Trichoderma hamatum isolate DS $219 \mathrm{~b}$ promotes growth and delays the onset of the drought response in Theobroma cacao. J Experimental Botany 60, 3279-3295. 
Bailey BA, Bae H, Strem MD, Roberts DP, Thomas SE, Crozier J, Samuels GJ, Choi IY, Holmes KA. 2006 - Fungal and plant gene expression during the colonization of cacao seedlings by endophytic isolates of four Trichoderma spp. Planta 224, 1449-1464.

Baldrian, P. 2008 - Wood-inhabiting ligninolytic basidiomycetes in soils: ecology and constraints for applicability in bioremediation. Fungal Ecology 1, 4-12.

Benitez T, Delgado-Jarana J, Rincón AM, Rey M, Limón MC. 1998 - Biofungicides: Trichoderma as a biocontrol agent against phytopathogenic fungi. In: Pandalai, S.G. (ed.) Recent Research Developments in Microbiology, vol. 2. Research Signpost, Trivandrum, Kerala, India, pp. 129-150.

Bennett AJ, Bending GD, Chandler D, Hilton S, Mills P. 2012 - Meeting the demand for crop production: the challenge of yield decline in crops grown in short rotations Biol. Rev. 87, $52-71$.

Bonfante P, Genre A. 2010 - Mechanisms underlying beneficial plant-fungus interactions in mycorrhizal symbiosis. Nat Commun, 1, 48. Retrieved from http://dx.doi.org/10.1038/ncomms1046

Brotman Y, Kapuganti JG, Viterbo A. 2010 - Trichoderma. Current Biology 20, 390-391.

Bulgarelli D, Rott M, Schlaeppi K, Ver Loren van TE, Ahmadinejad N, Assenza F, et al. 2012 Revealing structure and assembly cues for Arabidopsis root-inhabiting bacterial microbiota. Nature 488, 91-95.

Camehl I, Sherameti I, Venus Y, Bethke G, Varma A et al. 2010-Ethylene signalling and ethylene-targeted transcription factors are required to balance beneficial and nonbeneficial traits in the symbiosis between the endophytic fungus Piriformospora indica and Arabidopsis thaliana. New Phytologist 185, 1062-1073.

Chang YC, Baker R, Kleifeild O, Chet I. 1986 - Increased growth of plants in the presence of the biological agent Trichoderma harzianum. Plant Disease 70, 145-148.

Chet I, Inbar J, Hadar I. 1997 - Fungal antagonists and mycoparasites. In: Wicklow, D.T. and Soderstrom, B. (eds) The Mycota IV: Environmental and Microbial Relationships. Springer, Berlin, pp. 165-184.

Contreras-Cornejo HA, Macías-Rodríguez L, Cortés-Penagos C, López-Bucio J. 2009 Trichoderma virens, a Plant Beneficial Fungus, Enhances Biomass Production and Promotes Lateral Root Growth through an Auxin-Dependent Mechanism in Arabidopsis. Plant Physiology 149(3), 1579-1592.

Dana MM, Limon MC, Mejias R, Mach RL, Benitez T, Pintor-Toro JA, Kubicek CP. 2001 Regulation of chitinase 33 (chit33) gene expression in Trichoderma harzianum. Current Genetics, 38, 335-342.

Das A, Kamal S, Shakil Najam A, Sherameti I, Oelmüller R, Dua M, Tuteja N, Johri Atul K, Varma A. 2012 - The root endophyte fungus Piriformospora indica leads to early flowering, higher biomass and altered secondary metabolites of the medicinal plant, Coleus forskohlii. Plant Signal Behavior 7, 1-10.

Dennis PG, Miller AJ, Hirsch PR. 2010 - Are root exudates more important than other sources of rhizodeposits in structuring rhizosphere bacterial communities? FEMS Microbiol. Ecol. 72, 313-327.

Deshmukh S, Hückelhoven R, Schäfer P, Imani J, Sharma M et al. 2006- The root endophytic fungus Piriformospora indica requires host cell death for proliferation during mutualistic symbiosis with barley. Proceedings of National Academy of Science USA 103,18450 18457.

Elad Y, Freeman S, Monte E. 2000 - Biocontrol agents: mode of action and interaction with other means of control. IOBC Bulletin vol. 24. International Organization for Biological Control (IOBC), Seville, Spain.

Firakova S, Sturdikova M, Mučkova M. 2007 - Bioactive secondary metabolites produced by microorganisms associated with plants. Biologia 62, 251-257.

Fortuna A. 2012 - The Soil Biota. Nature Education Knowledge 3(10), 1. 
Franken P. 2012 - The plant strengthening root endophyte Piriformospora indica: potential application and the biology behind. Applied Microbiology Biotechnology 96: 1455-1464.

Gange AC, West HM. 1994 - Interactions between arbuscular mycorrhizal fungi and foliar-feeding insects in Plantago lanceolata L. New Phytology 128, 79-87.

Goltapeh ME, Danesh YR. 2006 - Pathogenic interactions between Trichoderma species and Agaricus bisporus. J Agric Technol 2, 29-37.

Harman GE, Howell CR, Viterbo A, Chet I, Lorito M. 2004 - Trichoderma species opportunistic, avirulent plant symbionts. Nature Reviews Microbiology 2, 43-56.

Harman G.E. (2000b) Trichoderma spp., including T. harzianum, T. viride, T. koningii, $T$. hamatum and other spp. Deuteromycetes, Moniliales (asexual classification system). Cornell University College of Agriculture and Life Sciences, New York. Available

Hebbar PK, Lumsden RD. 1999 - Biological control of seedling diseases. In: Methods in Biotechnology Vol. 5: Biopesticides: Use and Delivery (eds. R.H. Frinklin and J.M. Julius). Humana press: 103-116.

Kleifield O, Chet L. 1992 - Trichoderma harzianum - interaction with plants and effect on growth response. Plant and Soil 144, 267-272.

Kumar P, Misra AK, Modi DR, Gupta VK. 2012 - Biocontrol potential of Trichoderma species against mango malformation pathogens. Archives of Phytopathology and Plant Protection 45 (10), 1237-1245.

Lindsey DL and Baker R 1967 - Effect of certain fungi on dwarf tomatoes grown under gnotobiotic conditions. Phytopathology 57, 1262-1263.

Lumini E, Bianciotto V, Jargeat P, Novero M, Salvioli A, Faccio A, Bécard G, Bonfante P. 2007 Presymbiotic growth and sporal morphology are affected in the arbuscular mycorrhizal fungus Gigaspora margarita cured of its endobacteria. Cell Microbiol 9(7), 1716-29.

Lundberg D S, Yourstone S, Mieczkowski P, Jones C D, Dangl J. 2013 - Practical innovations for high-throughput amplicon sequencing. Nature Methods 10, 999-1002.

Lundberg DS, Lebeis SL, Paredes SH, Yourstone S, Gehring J, Malfatti S, et al. 2012 - Defining the core Arabidopsis thaliana root microbiome. Nature 488, 86-90.

Marschner H, Romheld V, Horst WJ, Martin P. 1986 - Root-induced changes in the rhizosphere: importance for the mineral nutrition of plants. Zeitschrift für Pflanzenernährung und Bodenkunde 149, 441-456.

Masunaka, A, Hyakumachi M, Takenaka S. 2011 - Plant growth promoting fungus Trichoderma koningii suppresses isoflavonoid phytoalexin vestitol production for colonization on/in the roots of Lotus japonicus. Microbes and Environments 26, 128-134.

Mendes R, Kruijt M, B Irene de, Dekkers E, van der Voort M, Schneider JHM, Piceno YM, DeSantis TZ, Andersen GL, Bakker AHMP, Raaijmakers J M. 2011 - Deciphering the rhizosphere microbiome for disease-suppressive bacteria. Science 332, 1097-1100.

Moran-Diez E, Hermosa R, Ambrosino P, Cardoza RE, Gutierrez S, Lorito M, Monte E. 2009 The ThPG1 endopolygalacturonase is required for the Trichoderma harzianum-plant beneficial interaction. Molecular Plant-Microbe Interactions 22, 1021-1031.

Mukherjee M, Mukherjee PK, Benjamin AH, Zachow H, Berg G, Zeilinger S. 2012 Trichoderma-plant-pathogen interactions: advances in genetics of biological control. Indian Journal of Microbiology 52(4), 522-529.

Nosir W, McDonald J, Woodward S. 2011 - Impact of biological control agents on fusaric acid secreted from Fusarium oxysporum f. sp. gladioli (Massey) Snyder and Hansen in Gladiolus grandiflorus corms.

Oelmüller R, Sherameti I, Tripathi S, Varma A. 2009 - Piriformospora indica, a cultivable root endophyte with multiple biotechnological applications. Symbiosis 49, 1-17.

Osiewacz HD. 2002 - Molecular Biology of Fungal Development. Marcel Dekker, New York, p. 587.

Pagano MC, Zandavalli RB, Araújo FS. 2013 - Biodiversity of arbuscular mycorrhizas in three vegetation types from the semiarid of Ceará State, Brazil. Applied Soil Ecology 67, 37-46. 
Papavizas GC, Lumsden RD. 1980 - Biological control of soil borne fungal propagules. Annual Review of Phytopathology 18, 389-413.

Parniske M. 2008. Arbuscular mycorrhiza: the mother of plant root endosymbioses. Nature Review in Microbiology 6, 763-775.

Paulitz TC, Belanger RR. 2001 - Biological control in greenhouse system. Annual Reviews Phytopathology 39, 103-133.

Peiffer JA, Spor A, Koren O, Jin Z, Tring SG, Dangl JL, et al. 2013 - Diversity and heritability of the maize rhizosphere microbiome under field conditions. Proceedings of National Academy of Science USA 16, 6548-6553.

Prasad RP. 2008 - Studies on interaction between symbiotic fungus (Piriformospora indica), rhizobacteria and selected plants. PhD Thesis,CCS Meerut University, India

Punja ZK, Utkhede RS. 2004 - Biological control of fungal diseases on vegetable crops with fungi and yeasts. In: Fungal Biotechnology in Agricultural, Food, and Environmental Applications (ed. D.K. Arora), New York Basel: 157-171.

Radford A, Stone PJ, Taleb F. 1996 - Cellulase and amylase complexes. In: Biosynthesis and Biodegradation of Cellulose (ed. Haigler C, Weimer P), pp. 535-597. Marcel Dekker, New York.

Rai MK, Acharya D, Varma A, Chikhale NJ, Wadegaonkar PA, Thakare PV, Ramteke AP, Kirpan P, Shende S. 2001 - Arbuscular mycorrhizal fungi in growth promotional of medicinal plants. National Workshop on Conservation of Medicinal Aromatic Plants held at CFHRD, Chhindwara, December 26-27, Proceedings, pp. 105-110.

Ryan MH, Graham JH. 2002 - Is there a role for arbuscular mycorrhizal fungi in production agriculture? Plant Soil 244, 263-271.

Schäfer P, Pfiffi S, Voll LM, Zajic D, Chandler PM et al. 2009 - Manipulation of plant innate immunity and gibberellin as factor of compatibility in the mutualistic association of barley roots with Piriformospora indica. Plant Journal 59, 461-474.

Schulz BJE, Boyle CJC, Sieber TN. 2006 - Microbial Root Endophytes. Vol. 9. Springer. pp. 1-13.

Shivanna MB, Meera MS, Hyakumachi M. 1994 - Sterile fungi from zoysia grass rhizosphere as plant growth promoters in spring wheat. Canadian Journal of Microbiology 40, 637-644.

Shivanna MB, Meera MS, Kageyama K, Hyakumachi M. 1996 - Growth promotion ability of zoysia grass rhizosphere fungi in consecutive plantings of wheat and soybean. Mycoscience 37, 163-168.

Shoresh M, Harman GE. 2008 - The molecular basis of shoot responses of maize seedlings to Trichoderma harzianum T22 inoculation of the root: a proteomic approach. Plant Physiology 147, 2147-2163.

Singh M. 2015 - Interactions among arbuscular mycorrhizal fungi, Trichoderma harzianum, Aspergillus niger and biocontrol of wilt of tomato. Archive Phytopathology and Plant Protection 48, 205-211.

Singh RK, Kumar P, Tiwari NN, Singh SP, Tiwari AK, Vishwakarma SK, Singh A, Kumar A. 2014 - Role of endochitinase gene and efficacy of Trichoderma against Colletotrichum falcatum Went. causing red rot disease in sugarcane. Sugar Tech 16 (2), 180-188.

Smith DL, Subramanian S, Lamont JR and Bywater-Ekegärd M. 2015 - Signaling in the phytomicrobiome: breadth and potential. Frontier Plant Sciences 6,709.

Smith SE, Read DJ. 2008. Mycorrhizal Symbiosis. New York: Elsevier.

Suurnakki A, Niku-Paavola ML, Buchert J, Viikari L. 2004 - Enzymes in pulp and paper processing. In: Aehle, W. (ed.) Enzymes in Industry. Wiley-VCH, Weinheim, Germany, pp. 232-244.

Sylvia DM, Fuharmann JJ, Hartel PG and Zuberer DA. 2005 - Biological control of soilborne plant pathogens and nematodes In. Principles and Applications of Soil Microbiology. Sylvia D.M., JJ Fuhrmann, PG Hartel, DA Zuberer. Upper Saddle River, NJ: Pearson Education, p.427-446. 
Unnikumar KR, Sowjanya SK, Varma A. 2013 - Piriformospora indica: a versatile root endophytic symbiont. Symbiosis 60, 107-113.

Vargas WA, Crutcher FK, Kenerley CM. 2011 - Functional characterization of a plant-like sucrose transporter from the beneficial fungus Trichoderma virens. Regulation of the symbiotic association with plants by sucrose metabolism inside the fungal cells. New Phytology 189, 777-789.

Verma S, Varma A, Rexer KH, Hassel A, Kost G et al. 1998 - Piriformospora indica, gen. et sp. nov., a new root-colonizing fungus. Mycologia 90, 896-903.

Varma A, Savita V, Sudha, Sahay N, Butehorn B et al. 1999 - Piriformospora indica, a cultivable plant-growth-promoting root endophyte. Applied and Environmental Microbiology 65, 2741-2744.

Varma A, Bakshi M, Lou B. 2012 - Piriformospora indica: A Novel Plant Growth-Promoting Mycorrhizal Fungus. Agricultural Research 1(2), 117-131.

Viterbo A, Chet I. 2006 - TasHyd1, a new hydrophobin gene from the biocontrol agent Trichoderma asperellum, is involved in plant root colonization. Molecular Plant Pathology 7, 249-258.

Viterbo A, Harel M, Horwitz BA, Chet I, Mukherjee PK. 2005 - Trichoderma mitogen-activated protein kinase signaling is involved in induction of plant systemic resistance. Applied and Environmental Microbiology 71, 6241-6246.

Viterbo A, Inbar J, Hadar Y, Chet I. 2007 - Plant disease biocontrol and induced resistance via fungal mycoparasites. In: Environmental and Microbial Relationships, 2nd edn. The Mycota IV. (eds. C.P. Kubicek and I.S. Druzhinina). Springer-Verlag Berlin Heidelberg: 127-146.

Viterbo A, Landau U, Kim S, Chernin L, Chet I. 2010 - Characterization of ACC deaminase from the biocontrol and plant growth-promoting agent Trichoderma asperellum T203. FEMS Microbiology Letters 305, 42-48.

Walley FL, Germida JJ. 1997 - Response of spring wheat (Triticum aestivum) to interactions between Pseudomonas species and Glomus clarum NT4. Biology and Fertility of Soils 24, 365-371.

Weiss M, Sýkorová Z, Garnica S, Riess K, Martos F et al. 2011 - Sebacinales Everywhere: Previously Overlooked Ubiquitous Fungal Endophytes. PLOS ONE 6: e167983.

Xia Y, DeBolt S, Dreyer J, Scott D, Williams MA. 2015 - Characterization of culturable bacterial endophytes and their capacity to promote plant growth from plants grown using organic or conventional practices. Frontiers in Plant Sciences 6, 490.

Xia Y, Petti C, Williams MA, DeBolt S. 2014 - Experimental approaches to study plant cell walls during plant-microbe interactions. Frontiers in Plant Sciences 5,540.

Yang T, Chen Y, X-X Wang, C-C Dai. 2013 - Plant symbionts: keys to the phytosphere. Symbiosis 59,1-14.

Yang Y, Han X, Liang Y, Ghosh A, Chen J, Tang M. 2015 - The Combined Effects of Arbuscular Mycorrhizal Fungi (AMF) and Lead (Pb) Stress on Pb Accumulation, Plant Growth Parameters, Photosynthesis, and Antioxidant Enzymes in Robinia pseudoacacia L. PLOS ONE, 10(12): e0145726.

Yedida I, Benhamou N, Kapulnik Y, Chet I. 2000 - Induction and accumulation of PR proteins activity during early stages of root colonization by the mycoparasite Trichoderma harzianum strain T-203. Plant Physiology and Biochemistry 38, 863-873. 